\title{
An example for transatlantic hitchhiking by macrozoobenthic organisms with a research vessel
}

\author{
Michael L. Zettler ${ }^{*}$ (1)
}

\begin{abstract}
In 2019 the RV Meteor cruised from Guadalupe in April/May to Cape Verde in June/July and to Namibia in August/ September. The distance is about 10,000 km. The ship has a moon pool for installation of instruments. In Cape Verde we had a first glimpse of the already sparsely populated moon pool. We reached Namibian waters in mid-August. In mid-September, 47 days later and 6000 km south, the ship's moon pool was sampled in the port of Walvis Bay. 13 different taxa could be identified belonging to two phyla, four classes, six orders and 10 families. Most of these species have not yet been observed in the port or in the adjacent areas and are new records for the entire Namibian coast. The goose barnacles Conchoderma auritum (Linnaeus, 1767), Conchoderma virgatum Spengler, 1789 and Lepas anatifera Linnaeus, 1758 were particularly noticeable. They were only surpassed by the large number of amphipods. The species Ericthonius brasiliensis (Dana, 1853), Jassa marmorata Holmes, 1905, Stenothoe senegalensis Krapp-Schickel, 2015 and Paracaprella pusilla Mayer, 1890 are particularly noteworthy here. In addition, the pycnogonid species Endeis straughani Clark, 1970 and the titan acorn barnacle Megabalanus coccopoma (Darwin, 1854) should be mentioned, which occurred very frequently as well. The present study shows, on the one hand, an example of the transatlantic spread of bioinvasive species by ships as vectors and, on the other hand, a convenient method for sampling ship hulls.
\end{abstract}

Keywords: Atlantic, Bioinvasion, Vector, Ship hull, Namibia

\section{Introduction}

Biological invasions continue to increase around the world, with impacts on many coastal marine systems. A large number of vectors for the spreading of marine organisms are conceivable, e.g. aquaculture, ship traffic, pet trade and tourism (e.g. [1-8]). One of the most important is certainly unintentional transport by ship. While larvae of endobenthic species can be carried over large distances in ballast water, epibenthic organisms are potentially able to survive longer distances attached to the ship's hull (e.g. $[9,10])$. The rate of biological invasions has strongly increased during the last

*Correspondence: michael.zettler@io-warnemuende.de Leibniz Institute for Baltic Sea Research, Seestraße 15, 18119 Rostock, Germany decades, mostly due to the accelerated spread of species by increasing global trade and transport [3].

Apparently Namibia has not been one of the hotspots of worldwide species introduction [3]. However after a very recent study even the temperate zone of southern Africa has a high risk of introduction of nonindigenous species (NIS) especially from eastern Indo-Pacific and temperate northern and tropical eastern Pacific [7]. In 2016 Alexander et al. [11] published a review paper on South African marine invasion literature and in 2020 Robinson et al. [12] listed 95 marine alien species (of which 56 have spread to become invasive) known from South African coast. Two main points emerge in relation to the present study. First, little to no attention has been paid to marine invasions in the countries bordering South Africa (here Namibia). Second, the role of 
harbours and marinas as sources and sinks of marine invasions along the Namibian coast is currently not well understood and should be addressed by future work. It is important to recognize that it is difficult to identify alien taxa when indigenous species are not well studied, in areas with little knowledge of biodiversity. The author has been researching the Namibian macrozoobenthos for several years (e.g. [13-15]). However, the coastal areas, especially the ports, were not yet in focus for me or any other effort.

The present study demonstrates the permanent risk of non-native species being moved from anywhere (here over a distance of probably up to $10,000 \mathrm{~km}$ ) to Namibia. A randomly initiated sampling of the colonization of a moon pool of a research vessel in the port of Walvis Bay yielded mostly previously unknown non-native species for Namibian waters.

\section{Material and methods}

A moon pool is a feature of research vessels (and some other ships as well). It is an opening in the floor of the hull giving access to the water below. It allows the exposition of sampling devices and instruments into the sea. It provides a protected access to the sea even on the high seas or long voyages. During a research cruise starting from Cape Verde and going to Namibia we installed some equipment (not relevant for the present study) at the moon pool at the beginning of August 2019 in Mindelo (Cape Verde). For this the platform was lifted out the water. The brackets and the platform of the moon pool were already sparsely populated by some organisms (Fig. 1), but neither investigated nor sampled. The ship was previously in the Caribbean Sea (April to May) and Cape Verde and North-West Africa (June to July). We reached Namibian waters in mid-August (see Fig. 2 for the route of the ship). At the end of the cruise in mid-September the devices of the moon pool were recovered. The platform was lifted out of the water again. I sampled the installation platform by scratching the surface randomly without any quantitative claim. Some larger taxa (goose barnacle) were specifically removed. The material was preserved in $4 \%$ buffered formalin. The platform was exposed to seawater continuously for at least 47 days. This meant that many organisms only had 47 days to colonize them. If you take into account the previous sections of the cruise, the exposure time has been increased: including the month around Northwest Africa to 79 days and including the transit from the Caribbean to a total of 113 days. The sample was analysed in the laboratory using a dissection microscope which a magnification of $\times 10$ (or higher). The species were determined and

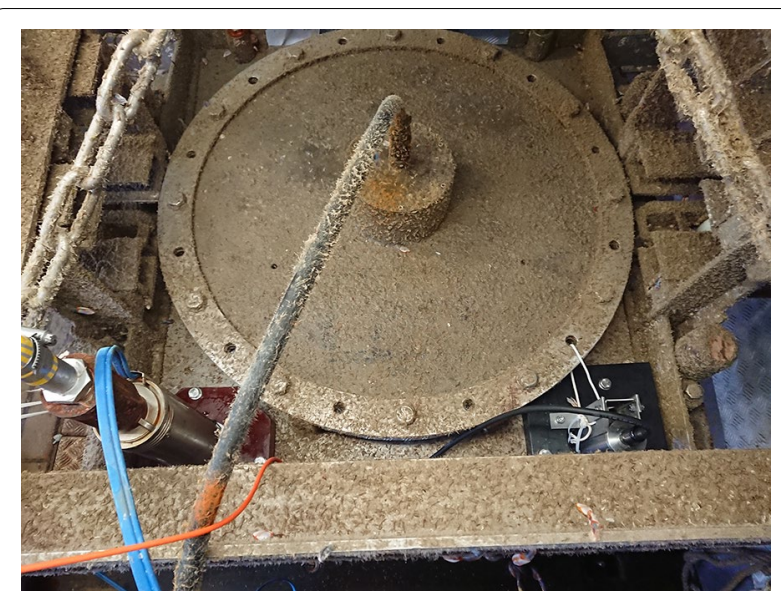

Fig. 1 At the beginning of installation of our device at 3rd August 2019 in Cape Verde already a sparse colonisation of the moon pool hardware was visible. Especially amphipod tubes, barnacles and some juvenile stages of goose barnacles could be seen (Photo: M. Glockzin)

counted. Although the sample was only qualitative, all individuals were counted. The most common species were roughly estimated $(>100$ or $>1000)$.

\section{Results}

At the beginning of the observation in Cape Verde, only a sparse but clear colonization of organisms was visible (Fig. 1). At the end of the cruise in Walvis Bay the community was much denser (Fig. 3A). The analyses of the scratch sample showed 13 different taxa belonging to two phyla, four classes, six orders and 10 families (Table 1). Most obvious were the large goose barnacles Conchoderma auritum (Linnaeus, 1767), Conchoderma virgatum Spengler, 1789 and Lepas anatifera Linnaeus, 1758 (Fig. 3). All of them were fully grown and vital.

Regarding the numbers the amphipods and some others dominated the sample (Table 1, Fig. 4). Ericthonius brasiliensis (Dana, 1853) found optimal conditions on the moon pool bracket and reached several thousand individuals. Stenothoe senegalensis Krapp-Schickel, 2015 with several hundred individuals followed in second place. Jassa marmorata Holmes, 1905 and Paracaprella pusilla Mayer, 1890 were both common too. In addition, the pycnogonid species Endeis straughani Clark, 1970 and the titan acorn barnacle Megabalanus coccopoma (Darwin, 1854) should be mentioned, which occurred very frequently as well. The amphipod Podocerus sp. and the decapods Plagusia sp. were only found as single individuals. From the swimming crab Liocarcinus sp. and also from the red-mouthed rock shell Stramonita haemastoma (Linnaeus, 1767) only some juveniles were observed. 


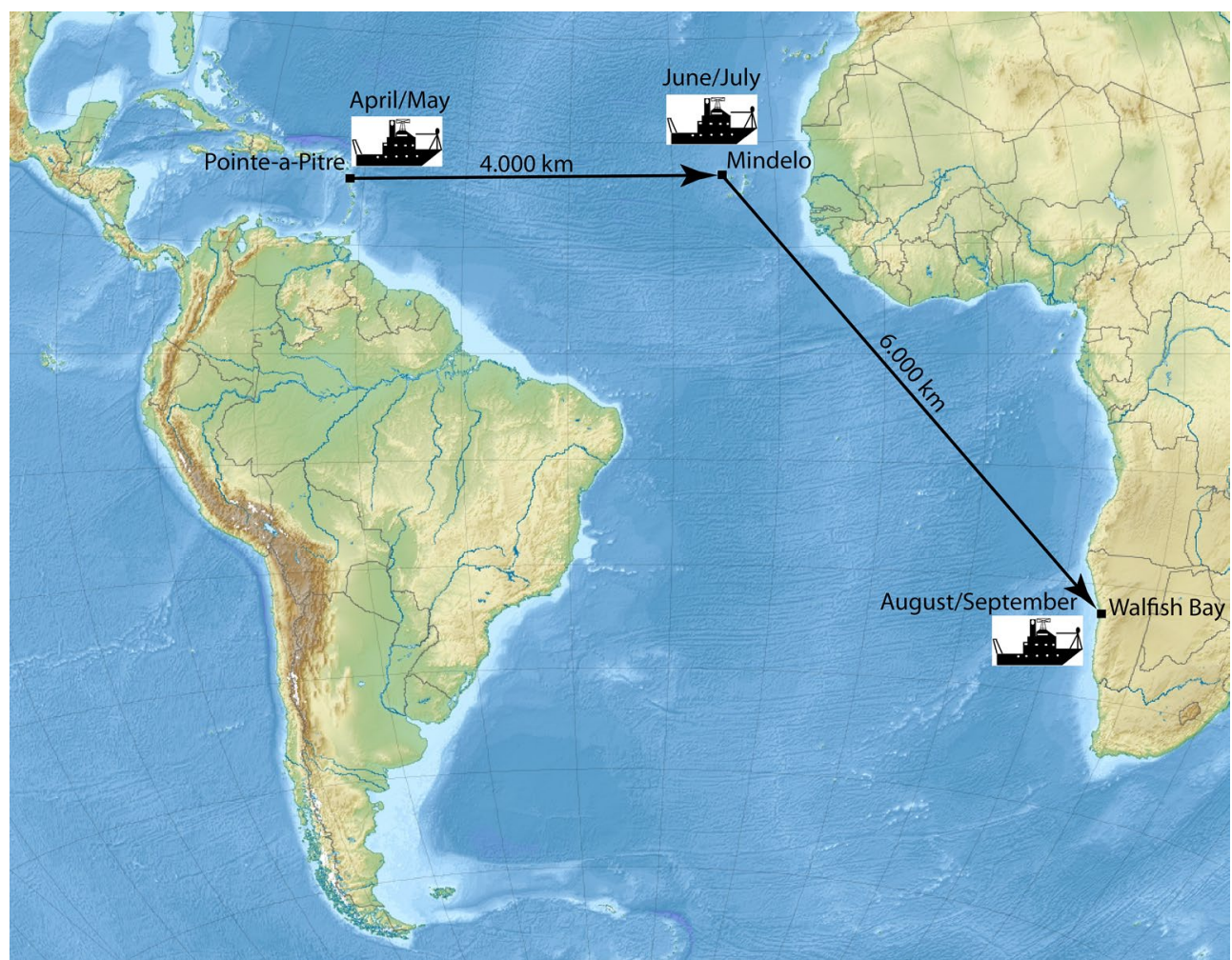

Fig. 2 The route of the research vessel from April to September 2019

\section{Discussion}

Among the species identified probably the goose barnacles (Lepas anatifera, Conchoderma virgatum and Conchoderma auritum) are the most common and widespread in the world. They show a cosmopolitan pattern of distribution, attached by their flexible stalks to floating wood and debris, the hulls of ships, piers, buoys, seaweed and larger animals as fishes, crocodiles, turtles or whales (e.g. [16-20]). They are often associated with each other, living in tropical, subtropical and boreal waters and are fast growing organisms. To the present, there is only one species reported for Namibian waters (a species of the genus Lepas) was described so far for Namibian waters (http://www.biodiversity.org.na) and also in South Africa the genus Conchoderma was not recorded so far [21]. However, since the species occur worldwide and are commonly spread by both shipping and whales, occurrence in Namibian waters would not be unexpected.

The titan acorn barnacle Megabalanus coccopoma originates from the tropical Pacific coasts of central and South America and has successfully invaded Brazilian waters, the North Sea, Japan, southeastern coast of the United States and also tropical West African waters [22 and references therein, 23]. The first observations on the West African coast were made at the Gambian coastline in 2010 [22]. Also in 2010 records were made at buoys in the entrance of the Ports of Richard's Bay and Durban in South Africa [24]. Due to its ability to biofouling on floating artificial surfaces, the species has high potential to spread around the world [22].

Among the amphipods Ericthonius brasiliensis was the most abundant one. Several thousand individuals of this tube building species occupied the platform of the moon pool. The tubes covered almost every open area of the platform. At the beginning of our survey (in Cape Verde), the tubes were already visible, albeit at a significantly reduced density (compare Figs. 1 and 3A). E. brasiliensis originates from the Atlantic coast of South America and is one of the most successful invaders around the world. The species is also known from South Africa [25], but has not yet been reported from Namibia. In South Africa, it is also known from the South Benguela ecoregions, an area that borders Namibia [12]. The present material has been certainly distinguished from the similar species $E$. punctatus (Spence Bate, 1857) and E. parabrasiliensis Just, 2009 [26].

Next to the previous species Jassa marmorata was frequently observed within the sample. J. marmorata is native to the North-West Atlantic but has been introduced to several places around the world. The species 

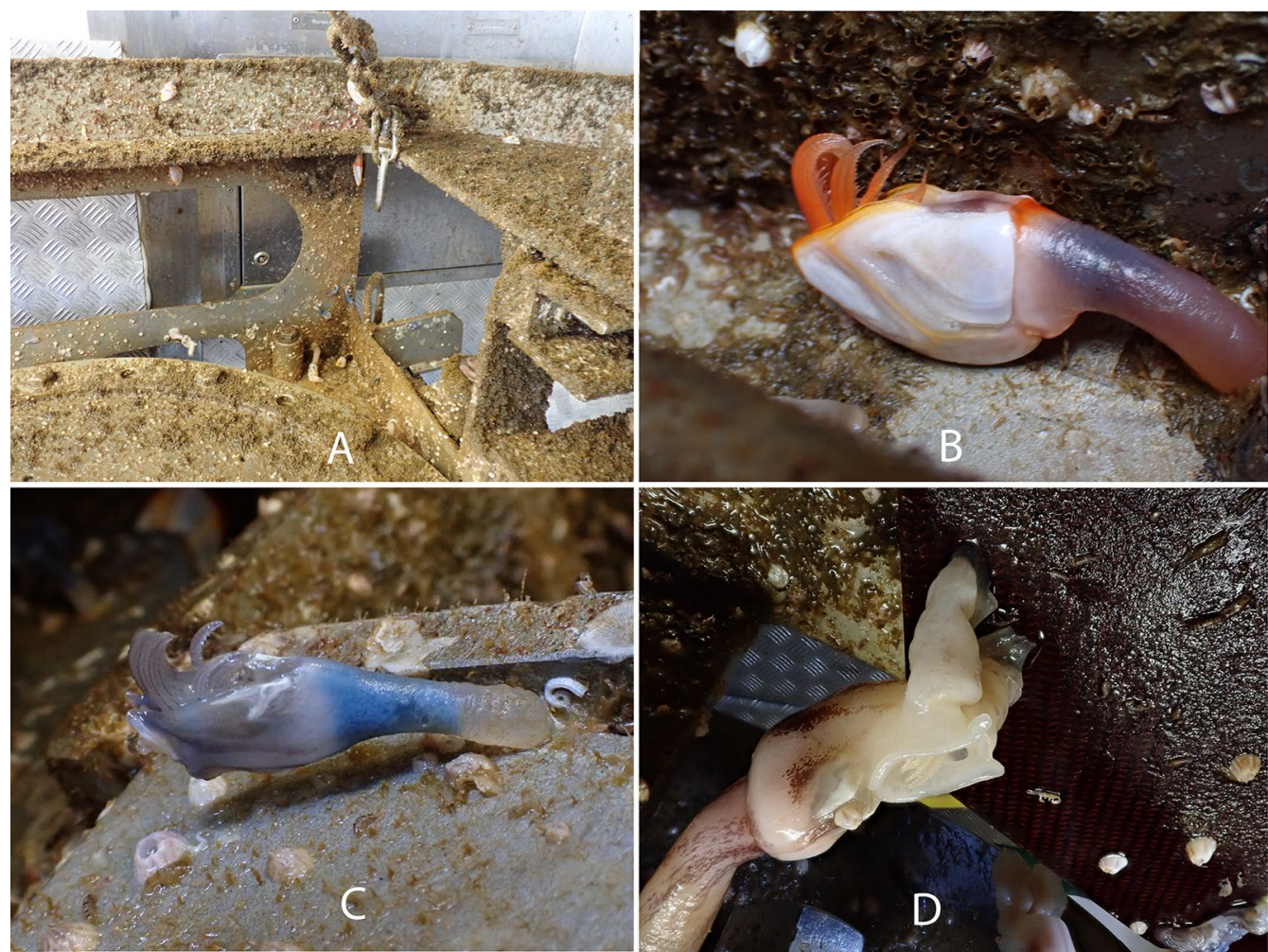

Fig. 3 At the end of our cruise the colonization of organisms was much denser (A) and especially the goose barnacles (B-D) were fully grown: B Lepas anatifera Linnaeus, 1758, C Conchoderma virgatum Spengler, 1789, D Conchoderma auritum (Linnaeus, 1767)

Table 1 List of observed taxa from the RV Meteor moon pool sampled at 15th September 2019 in Walvis Bay (Namibia)

\begin{tabular}{|c|c|c|c|c|c|}
\hline Class & Order & Family & Taxon & Origin & No \\
\hline Gastropoda & Neogastropoda & Muricidae & Stramonita haemastoma (Linnaeus, 1767) & Western Atlantic & 10 \\
\hline Hexanauplia & Lepadiformes & Lepadidae & Conchoderma auritum (Linnaeus, 1767) & cosmopolitan & 3 \\
\hline Hexanauplia & Lepadiformes & Lepadidae & Conchoderma virgatum Spengler, 1789 & cosmopolitan & 5 \\
\hline Hexanauplia & Lepadiformes & Lepadidae & Lepas anatifera Linnaeus, 1758 & cosmopolitan & 15 \\
\hline Hexanauplia & Sessilia & Balanidae & Megabalanus coccopoma (Darwin, 1854) & Pacific & $>100$ \\
\hline Malacostraca & Amphipoda & Caprellidae & Paracaprella pusilla Mayer, 1890 & Caribbean & $>50$ \\
\hline Malacostraca & Amphipoda & Ischyroceridae & Ericthonius brasiliensis (Dana, 1853) & West-Atlantic & $>1000$ \\
\hline Malacostraca & Amphipoda & Ischyroceridae & Jassa marmorata Holmes, 1905 & North-East Atlantic & $>100$ \\
\hline Malacostraca & Amphipoda & Podoceridae & Podocerus sp. & $?$ & 1 \\
\hline Malacostraca & Amphipoda & Stenothoidae & Stenothoe senegalensis Krapp-Schickel, 2015 & Senegal & $>100$ \\
\hline Malacostraca & Decapoda & Plagusiidae & Plagusia sp. & $?$ & 1 \\
\hline Malacostraca & Decapoda & Polybiidae & Liocarcinus sp. & $?$ & 12 \\
\hline Pycnogonida & Pantopoda & Endeidae & Endeis straughani Clark, 1970 & Atlantic-Pacific & $>50$ \\
\hline
\end{tabular}

can also be called a globetrotter. A recent study found that J. marmorata (and also Jassa slatteryi Conlan, 1990) began long ago to colonize the oceans and they call this type "neocosmopolitans" [27]. According to Griffiths et al. [28] J. marmorata was already observed in South Africa in the 1950s. In Picker and Griffiths
[29] and in Robinson et al. [12] only J. slatteryi was mentioned. However, Conlan [30] confirms that both J. marmorata and J. slatteryi occur in South Africa. In the present material the characteristics clearly show that it is J. marmorata. The study by Conlan [30] was used to differentiate the species. 


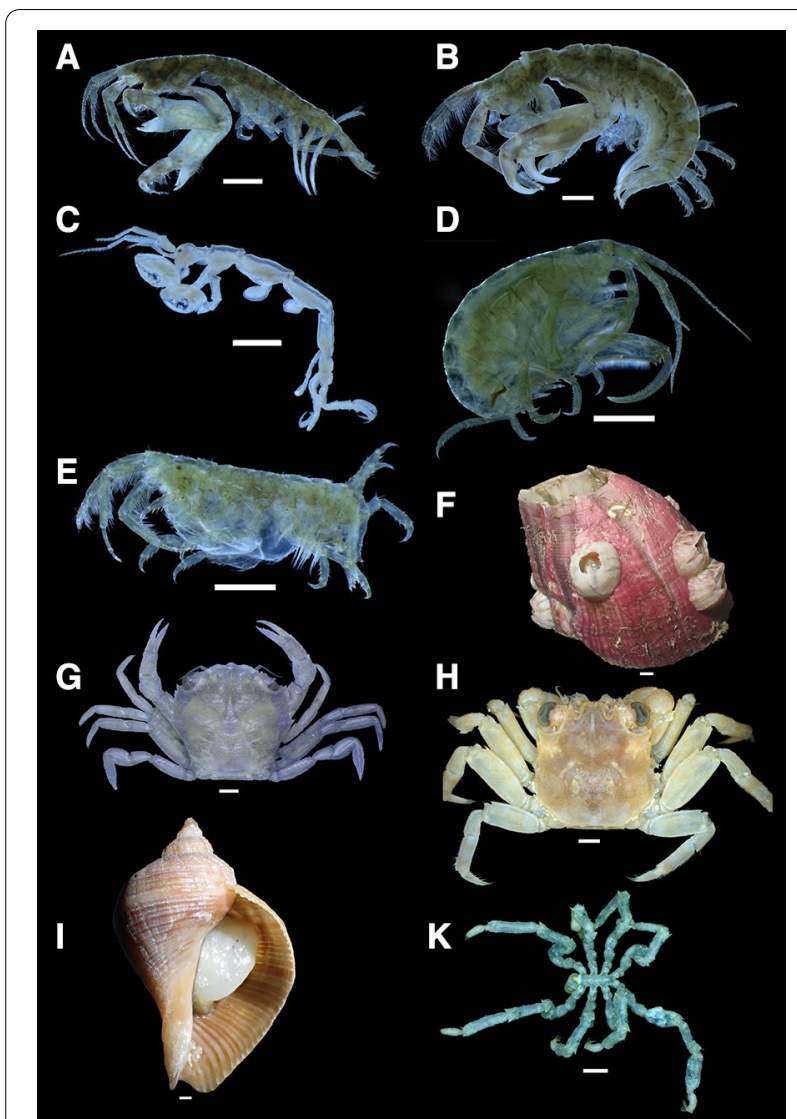

Fig. 4 Found marine invertebrates $\mathbf{A}$ Ericthonius brasiliensis, B Jassa marmorata, C Paracaprella pusilla, D Stenothoe senegalensis, E Podocerus sp., F Megabalanus coccopoma, G Liocarcinus sp., H Plagusia sp., I Stramonita haemastoma, K Endeis charybdaea, Scale bars: 1 mm

For determination of Stenothoe senegalensis the key by Krapp-Schickel [31] was used. It belongs to the Stenothoe gallensis species complex that has not been fully resolved. S. gallensis Walker, 1904 described from Sri Lanka, ranges from South Africa to South China Sea [31]. S. senegalensis is named after its type locality in Senegal and so far only known from there. Following the argumentation of Krapp-Schickel [31] on the distinction between the two species, I come here to $S$. senegalensis. With more than 100 individuals in my scratch sample this tiny amphipod achieved high abundances. Cape Verde lies only few hundred kilometres off the Senegalese coast and it is very likely that this species can also be found on the coast around the islands, the starting point of our research cruise.

One of the most successful caprellid amphipod invaders on fouling substrates around the world (Paracaprella pusilla) has arrived in almost all parts of tropical, subtropical and temperate waters [32-36]. Previously it was mainly reported from subtropical and tropical waters [32]. The present observation from the port of Walvis
Bay seems to be unsuitable for this species in terms of the water temperature (it is around $12{ }^{\circ} \mathrm{C}$ ). However, we previously sailed in Namibian waters for about 35 days and the high numbers of $P$. pusilla in the sample and their mobility show that the species can obviously handle it. The origin of the individuals we had in my sample could be Guadalupe, where the species was previously observed [32].

For determination of the sea spiders (Pycnogonida) I used the studies of Clark [37], Krapp [38] and Bamber [39, 40]. Endeis straughani is originally described from Queensland in Australia [37]. Later Bamber [39] introduced a new Endeis species from the coast of Ghana (West Africa) and named it Endeis picta, interestingly associated within a Megabalanus tintinnabulum fouling community at the ship hull of a returning ship to River Tyne in England. This species was later synonymized with $E$. straughani (see in http://www.marinespecies.org). Some distinct characteristics of E. straughani (robust species, leg segments much shorter and stout, recurved spines on the oviger segment 7) make it easy to distinguish it from E. charybdaea, a species common in the north-east Atlantic and Mediterranean [38, 40]. Fascinatingly, Clark [37] emphasized the greenish colour (even in alcohol-fixed animals). So far no occurrences of the genus Endeis are known in Namibia. The present evidence of $E$. straughani makes an occurrence on the previous shipping route in the North Atlantic very likely.

Stramonita haemastoma is widespread in tropical and warm waters in both the eastern and western Atlantic. It is known for West Africa (e.g. [41]) and is also rarely observed in North Namibian waters (own observations). In my samples of the moon pool it only occurs as young animals (maximum height $22 \mathrm{~mm}$ ), but the determination was possible.

Some species have been detected only once (Podocerus sp.) and/or were juveniles (Liocarcinus sp. Plagusia sp.). In these cases it was not possible to identify with certainty at the species level. Six species of the genus Podocerus are known so far for South Africa [25] and two of them probably also for Namibia (http:// www.biodiversity.org.na). In my sample, there was only one female that could not be identified. In the biodiversity data base of Namibia Guinusia chabrus (Linnaeus, 1758) (synonym Plagusia chabrus) is registered. Emmerson [42] listed G. chabrus and Plagusia depressa (Fabricius, 1775) for Namibian waters. In the present study these species cannot be confirmed nor excluded. The individual found was a juvenile with a carapace diameter of $6 \mathrm{~mm}$ and could not be identified with certainty. Both the carapace and the pereiopods were markedly less spiny than is typical for G. chabrus and P. depressa. Also the surface is not covered by fine hairs. The genus 
Liocarcinus was not recorded for Namibia so far. For this region only two species of Polybiidae have been found, namely Bathynectes piperitus R.B. Manning and Holthuis, 1981 and Macropipus australis Guinot, 1961 [42]. Both species can be excluded for the present individuals.

\section{Conclusions}

Ship hulls as a transport vector over long distances are well known. The present study shows, on the one hand, an example of the transatlantic spread of bioinvasive species and, on the other hand, a convenient method for sampling ship hulls. The moon pool as part of research vessels (and many other vessels) can easily be sampled while in ports or even offshore. Obviously it would have been very interesting to compare the species in the moon pool with those on the outer hull to answer the question were these species transported simply because of the unusual structure of this moon pool. This was not done; However, I would expect most species to be perfect for attachment to the outer hull as well. Therefore it would probably make little sense for ships with moon pools to clean or sterilize them before entering ports, while the largest area (outer hull) remains untreated for logistical reasons.

The arrival of several species in Namibian waters is described; most of them were recorded here for the first time. Walvis Bay as the largest (and next to Lüderitz the only) port in Namibia plays an important role in the spread of bioinvasive species along the south-west African coast. Finally, it should be noted that at this stage it is not clear which of these species can establish themselves in Namibia. It must be clear that finding fouling organisms on a ship or in the surrounding water do not necessarily mean that those organisms were/are introduced in any given region where the ship was/is at a given moment, or that those species will succeed in surviving there. The study aims to highlight the high risk of introducing exotic species through shipping on Namibia's shores (and elsewhere). However, the routine sampling of the vessels moon pool before and after voyages could deliver an interesting dataset for neobiota management. Alternatively, the systematic sampling of multiple ships visiting Walvis Bay could provide interesting information about the possible spread pressure. However, although species often occur on vessels they are not able to survive coastal conditions and do not pose an invasion risk. Therefore, maybe most useful would be sampling the port itself to quantify and document alien biota. Ultimately, the present study is a first approach to this problem in Namibian waters and it becomes clear how great the risk of the introduction of organisms is.

\section{Acknowledgements}

For determining help I wish to thank Werner Massier (Swakopmund) for Stramonita haemastoma (Linnaeus, 1767) and José M. Guerra-García (Sevilla) for Paracaprella pusilla Mayer, 1890. I would like to thank Michael Glockzin (Rostock), who made the photo 1 available to me and made me aware of the moon pool. The present study was part of a project funded by the Federal Ministry of Education and Research (Grant No. 03V01279).

\section{Authors' contributions}

The author read and approved the final manuscript.

\section{Funding}

Open Access funding enabled and organized by Projekt DEAL. The present study was part of a project funded by the Federal Ministry of Education and Research (Grant No. 03V01279).

\section{Availability of data and materials}

The datasets generated during and/or analysed during the current study are available in the IOW repository and are available from the author on reasonable request.

\section{Declarations}

Ethics approval and consent to participate

Not applicable.

Consent for publication

Not applicable.

\section{Competing interests}

The author declares that he has no competing interests" in this section.

Received: 16 December 2020 Accepted: 20 May 2021

Published online: 03 June 2021

\section{References}

1. Minchin D, Gollasch S, Cohen AN, Hewitt CL, Olenin S. Characterizing vectors of marine invasion. In: Rilov G, Crooks JA, editors. Biological invasions in marine ecosystems. Ecological, management and geographic perspectives. Berlin: Springer; 2009. p. 109-16.

2. Rilov G, Crooks JA. Marine bioinvasions: Conservation hazards and vehicles for ecological understanding. In: Rilov G, Crooks JA, editors. Biological invasions in marine ecosystems. Ecological, management and geographic perspectives. Berlin: Springer; 2009. p. 3-11.

3. Seebens H, Gastner MT, Blasius B. The risk of marine bioinvasion caused by global shipping. Ecol Lett. 2013;16:782-90.

4. McCollin T, Brown L. Native and non-native marine biofouling species present on commercial vessels using Scottish dry docks and harbours. Manag Biol Inv. 2014:5:85-96.

5. Ulman A, Ferrario J, Forcada A, Seebens H, Arvanitidis C, OcchipintiAmbrogi $A$, et al. Alien species spreading via biofouling on recreational vessels in the Mediterranean Sea. J Appl Ecol. 2019;56:2620-9.

6. Patoka J, Prabowo RE, Petrtýl M, Reynolds JD, Kuříková P, ZámečníkováWanma BPD, et al. Marine hitchhikers: a preliminary study on invertebrates unintentionally transported via the international pet trade. NeoBiota. 2020;61:33-46

7. Saebi M, Xu J, Grey EK, Lodge DM, Corbett JJ, Chawla N. Higher-order patterns of aquatic species spread through the global shipping network. PLOS ONE. 2020;15(7):e0220353.

8. Meloni M, Correa N, Pitombo FB, Chiesa IL, Doti B, Elías R, et al. In-water and dry-dock hull fouling assessments reveal high risk for regional translocation of nonindigenous species in the southwestern Atlantic. Hydrobiologia. 2021;848:1981-96

9. Gollasch S. The importance of ship hull fouling as a vector of species introduction into the North Sea. Biofouling. 2002;18:105-21.

10. Hewitt CL, Gollasch S, Minschin D. The vessel as a vector - biofouling ballast water and sediments. In: Rilov G, Crooks JA, editors. Biological 
invasions in marine ecosystems. Ecological, management and geographic perspectives. Berlin: Springer; 2009. p. 117-31.

11. Alexander ME, Simon CA, Griffiths CL, Peters K, Sibanda S, Miza S, et al. Back to the future: reflections and directions of South African marine bioinvasion research. Afr J Mar Sci. 2016;38:141-4.

12. Robinson TB, Peters K, Brooker B. Coastal invasions: the South African context. In: van Wilgen BW, Measey J, Richardson DM, Wilson JR, Zengeya TA, editors. Biological invasions in South Africa, invading nature, Springer series in invasion ecology. Cham: Springer; 2020. p. 229-47.

13. Zettler ML, Bochert R, Pollehne F. Macrozoobenthos diversity in an oxygen minimum zone off northern Namibia. Mar Biol. 2009:156:1949-61.

14. Zettler ML, Pollehne F. Namibian upwelling and its effects on macrozoobenthic diversity. In: Fischer WE, Green AB, editors. Upwelling: Mechanisms, ecological effects and threats to biodiversity. Hauppauge: Nova Science Publishers; 2013. p. 35-58.

15. Eisenbarth $\mathrm{S}$, Zettler ML. Diversity of the benthic macrofauna off northern Namibia from the shelf to the deep sea. J Mar Syst. 2016;155:1-10.

16. Evans F. Growth and Maturity of the Barnacles Lepas hillii and Lepas anatifera. Nature. 1958;4644:1245-6.

17. Nilsson-Cantell C-A. Cirripedia Thoracica and Acrothoracica. Marine invertebrates of Scandinavia, Number 5. Oslo: Universitetsforlaget; 1978.

18. Hayward PJ, Ryland JS. Handbook of the Marine Fauna of North-West Europe. Oxford: University Press; 1990.

19. Barreiros JP, Teves M. The sunfish Mola mola as an attachment surface for the Lepadid Cirriped Lepas anatifera - a previously unreported association. Aqua J Ichthyol Aquat Biol. 2005;10:1-4.

20. Cupul-Magaña FG, Rubio-Delgado A, Escobedo-Galván AH, Reyes-Núñez C. First report of the marine barnacles Lepas anatifera and Chelonibia testudinaria as epibionts on American crocodile (Crocodylus acutus). Herpetol Notes. 2011;4:213-4.

21. Whitehead TO, Biccard A, Griffiths CL. South African pelagic goose barnacles (Cirripedia, Thoracica): Substratum preferences and influence of plastic debris on abundance and distribution. Crustaceana. 2011;84:635-49.

22. Kerckhof F, Haelters J, Degraer S. The barnacles Chirona (Striatobalanus) amaryllis (Darwin 1854) and Megabalanus coccopoma (Darwin 1854) (Crustacea, Cirripedia): two invasive species new to tropical West African waters. Afr J Mar Sci. 2010;32:265-8.

23. Fofonoff PW, Ruiz GM, Steves B, Simkanin C, Carlton JT. National Exotic Marine and Estuarine Species Information System. 2018. http://invasions. si.edu/nemesis/. Accessed 20 Oct 2020.

24. Biccard A, Griffiths CL. Additions to the barnacle (Crustacea: Cirripedia) fauna of South Africa. Afr Zool. 2010:51:99-116.

25. Milne R, Griffiths CL. Additions to and revisions of the amphipod (Crustacea: Amphipoda) fauna of South Africa, with a list of currently known species from the region. Afr Nat Hist. 2013;9:61-90.

26. Gouillieux B, Ariyama H, Costa AC, Daffe G, Marchini A, Micael J, et al. New records of Ericthonius didymus Krapp-Schickel, 2013 (Crustacea: Amphipoda: Ischyroceridae) in European waters with a focus in Arcachon Bay, France and key to Ericthonius species. J Mar Biol Assoc UK. 2020;100:401-12.

27. Beermann J, Hall-Mullen AK, Havermans C, Coolen JW, Crooijmans RP, Dibbits B, et al. Ancient globetrotters - connectivity and putative native ranges of two cosmopolitan biofouling amphipods. PeerJ. 2020;8:e9613.
28. Griffiths $C L$, Robinson TB, Mead A. The status and distribution of marine alien species in South Africa. In: Rilov G, Crooks JA, editors. Biological invasions in marine ecosystems. Ecological, management and geographic perspectives. Berlin: Springer; 2009. p. 393-408.

29. Picker M, Griffiths CL. Alien and invasive animals, a South African perspective. Cape Town: Struik Publishers; 2011.

30. Conlan KE. Revision of the crustacean amphipod genus Jassa Leach (Corophioidea: Ischyroceridae). Can J Zool. 1990;68:2031-75.

31. Krapp-Schickel T. Minute but constant morphological differences within members of Stenothoidae: the Stenothoe gallensis group with four new members, keys to Stenothoe worldwide, a new species of Parametopa and Sudanea n. gen. (Crustacea: Amphipoda). J Nat Hist. 2015:49:2309-77.

32. Ros M, Guerra-García JM. On the occurrence of the tropical caprellid Paracaprella pusilla Mayer, 1890 (Crustacea: Amphipoda) in Europe. Mediterr Mar Sci. 2012;13:134-9.

33. Ros M, Vázquez-Luis M, Guerra-García JM. The tropical caprellid amphipod Paracaprella pusilla: a new alien crustacean in the Mediterranean Sea. Helgol Mar Res. 2013;67:675-85.

34. Alarcón-Ortega LC, Rodríguez-Troncoso AP, Cupul-Magaña AL. First record of non-indigenous Paracaprella pusilla Mayer, 1890 (Crustacea: Amphipoda) in the Northern Tropical East Pacific. Biolnv Rec. 2015:4:211-5

35. Cabezas MP, Ros M, dos Santos AM, Martínez-Laiz G, Xavier R, Montelli L, et al. Unravelling the origin and introduction pattern of the tropical species Paracaprella pusilla Mayer, 1890 (Crustacea, Amphipoda, Caprellidae) in temperate European waters: first molecular insights from a spatial and temporal perspective. NeoBiota. 2019;47:43-80.

36. Lo Brutto S, laciofano D, Guerra García JM, Lubinevsky H, Galil BS. Desalination effluents and the establishment of the non-indigenous skeleton shrimp Paracaprella pusilla Mayer, 1890 in the south-eastern Mediterranean. Biolnv Rec. 2019;8:661-9.

37. Clark WL. New Pycnogonida from Queensland. Trans Roy Soc New Zealand Biol Sci. 1970;12:13-20.

38. Krapp F. New records of Endeis charybdaea (Dohrn, 1881) (Pycnogonida) in the Atlantic and Mediterranean seas. Sarsia. 1975;59:85-94.

39. Bamber RN. A new species of Endeis (Pycnogonida) from West Africa. Zool J Linn Soc. 1979:65:251-4.

40. Bamber RN. Sea-spiders (Pycnogonida) of the north-east Atlantic. Synopsis of the British Fauna (New Series) 5. 2nd ed. Shrewsbury: FSC Publications; 2010.

41. Ardovini R, Cossignani T. West African Seashells. Ancona: L'Informatore Piceno; 2004.

42. Emmerson WD. A Guide to, and Checklist for, the Decapoda of Namibia, South Africa and Mozambique, vol. 1-3. Newcastle-upon-Tyne: Cambridge Scholars Publishing; 2016.

\section{Publisher's Note}

Springer Nature remains neutral with regard to jurisdictional claims in published maps and institutional affiliations.

Ready to submit your research? Choose BMC and benefit from:

- fast, convenient online submission

- thorough peer review by experienced researchers in your field

- rapid publication on acceptance

- support for research data, including large and complex data types

- gold Open Access which fosters wider collaboration and increased citations

- maximum visibility for your research: over $100 \mathrm{M}$ website views per year

At BMC, research is always in progress.

Learn more biomedcentral.com/submissions 